\title{
Research Priorities for Achieving Healthy Marine Ecosystems and Human Communities in a Changing Climate
}

OPEN ACCESS

Edited by:

Rui Rosa,

University of Lisbon, Portugal

Reviewed by:

Gil Rilov,

University of Haifa, Israel

Paulo Da Cunha Lana,

Federal University of Paraná, Brazil

*Correspondence:

Whitney R. Friedman

friedman@nceas.ucsb.edu

Specialty section:

This article was submitted to Global Change and the Future Ocean,

a section of the journal

Frontiers in Marine Science

Received: 20 June 2019 Accepted: 07 January 2020

Published: 28 January 2020

Citation:

Friedman WR, Halpern BS,

McLeod E, Beck MW, Duarte CM, Kappel CV, Levine A, Sluka RD,

Adler S, O'Hara CC, Sterling EJ,

Tapia-Lewin S, Losada IJ,

McClanahan TR, Pendleton $L$,

Spring M, Toomey JP, Weiss KR, Possingham HP and Montambault JR

(2020) Research Priorities

for Achieving Healthy Marine

Ecosystems and Human

Communities in a Changing Climate.

Front. Mar. Sci. 7:5.

doi: 10.3389/fmars.2020.00005
Whitney R. Friedman $12 *$ Beniamin S. Halpern 13 Elizabeth McLeod4, Michael W. Beck50 Carlos M. Duarte ${ }^{7}$, Carrie V. Kappel' ${ }^{1}$, Arielle Levine ${ }^{8}$, Robert D. Sluka ${ }^{9}$, Steven Adler ${ }^{10}$, Casey C. O'Hara ${ }^{3}$, Eleanor J. Sterling ${ }^{11}$, Sebastian Tapia-Lewin ${ }^{3}$, Iñigo J. Losada ${ }^{12}$, Tim R. McClanahan ${ }^{13}$, Linwood Pendleton 14,15,16,17, Margaret Spring ${ }^{18}$, James P. Toomey ${ }^{19}$, Kenneth R. Weiss ${ }^{20}$, Hugh P. Possingham ${ }^{2,21}$ and Jensen R. Montambault 22,23

${ }^{1}$ National Center for Ecological Analysis and Synthesis, University of California, Santa Barbara, Santa Barbara, CA, United States, ${ }^{2}$ The Nature Conservancy, Arlington, VA, United States, ${ }^{3}$ Bren School of Environmental Science and Management, University of California, Santa Barbara, Santa Barbara, CA, United States, ${ }^{4}$ The Nature Conservancy, Austin, TX, United States, ${ }^{5}$ The Nature Conservancy, University of California, Santa Cruz, Santa Cruz, CA, United States, ${ }^{6}$ Department of Ocean Sciences, University of California, Santa Cruz, Santa Cruz, CA, United States, ${ }^{7}$ Red Sea Research Center, King Abdullah University of Science and Technology, Thuwal, Saudi Arabia, ${ }^{8}$ Department of Geography, San Diego State University, San Diego, CA, United States, ${ }^{9}$ Marine and Coastal Conservation Programme, A Rocha International, London, United Kingdom, ${ }^{10}$ Ocean Data Alliance, New York, NY, United States, ${ }^{11}$ Center for Biodiversity and Conservation, American Museum of Natural History, New York, NY, United States, ${ }^{12}$ Environmental Hydraulics Institute, IH Cantabria, Universidad de Cantabria, Santander, Spain, ${ }^{13}$ Global Marine Program, Wildlife Conservation Society, Bronx, NY, United States, ${ }^{14} \mathrm{Global}$ Science, World Wildlife Fund, Washington, DC, United States, ${ }^{15}$ Ifremer, University of Brest, CNRS, UMR 6308, AMURE, IUEM, Plouzane, France, ${ }^{16} \mathrm{Global}$ Change Institute, The University of Queensland, St. Lucia, QLD, Australia, ${ }^{77}$ Duke University Marine Laboratory and Nicholas Institute for Environmental Policy Solutions, Durham, NC, United States, ${ }^{18}$ Conservation and Science, Monterey Bay Aquarium, Monterey, CA, United States, ${ }^{19}$ Sherman's Lagoon, Baltimore, MD, United States, ${ }^{20}$ Pulitzer Center on Crisis Reporting, Washington, DC, United States, ${ }^{21}$ School of Biological Sciences, The University of Queensland, St. Lucia, QLD, Australia, ${ }^{22}$ Science for Nature and People Partnership, The Nature Conservancy, Charlottesville, VA, United States, ${ }^{23}$ School of Earth and Environmental Sciences, The University of Queensland, St. Lucia, QLD, Australia

The health of coastal human communities and marine ecosystems are at risk from a host of anthropogenic stressors, in particular, climate change. Because ecological health and human well-being are inextricably connected, effective and positive responses to current risks require multidisciplinary solutions. Yet, the complexity of coupled social-ecological systems has left many potential solutions unidentified or insufficiently explored. The urgent need to achieve positive social and ecological outcomes across local and global scales necessitates rapid and targeted multidisciplinary research to identify solutions that have the greatest chance of promoting benefits for both people and nature. To address these challenges, we conducted a forecasting exercise with a diverse, multidisciplinary team to identify priority research questions needed to promote sustainable and just marine social-ecological systems now and into the future, within the context of climate change and population growth. In contrast to the traditional reactive cycle of science and management, we aimed to generate questions that focus on what we need to know, before we need to know it. Participants were presented with the question, "If we were managing oceans in 2050 and looking back, what research, primary or synthetic, would wish we had invested in today?" We first identified 
major social and ecological events over the past 60 years that shaped current human relationships with coasts and oceans. We then used a modified Delphi approach to identify nine priority research areas and 46 questions focused on increasing sustainability and well-being in marine social-ecological systems. The research areas we identified include relationships between ecological and human health, access to resources, equity, governance, economics, resilience, and technology. Most questions require increased collaboration across traditionally distinct disciplines and sectors for successful study and implementation. By identifying these questions, we hope to facilitate the discourse, research, and policies needed to rapidly promote healthy marine ecosystems and the human communities that depend upon them.

Keywords: marine sustainability, human health, social equity, climate change, priority research, sustainable development goals

\section{INTRODUCTION}

Human health and well-being are intricately linked to natural environments, including marine ecosystems (Whitmee et al., 2015). Around the world, seafood provides critical nutrition to more than 3 billion people (Béné et al., 2016; Golden et al., 2016; FAO, 2018). Fisheries and aquaculture directly employ more than 59.6 million people (FAO, 2018) and provide livelihoods for three to four times as many people through ancillary professions (e.g., processing, marketing, equipment production) (FAO, 2012; Teh and Sumaila, 2013). Marine ecosystems play a major role in global carbon sequestration and oxygen production (Duarte and Agustí, 1998; Sabine et al., 2004; McLeod et al., 2011; Pendleton et al., 2012). Healthy coral reefs, mangrove forests, and seagrass meadows are increasingly recognized as cost-effective natural buffers protecting coastal communities against flooding and coastal erosion (Spalding et al., 2014; Guannel et al., 2016; Narayan et al., 2017; Beck et al., 2018; Reguero et al., 2018), in addition to their role in carbon cycling and supporting fisheries (Duarte et al., 2013). Additionally, marine organisms are harvested for use as fertilizer, animal feed, and medical compounds (Froehlich et al., 2018b). Healthy marine ecosystems support a wide variety of industries and livelihoods, as well as the supply chains that support these sectors (World Bank, 2012; National Oceanic and Atmospheric Administration and National Marine Fisheries Service [NOAA-NMFS], 2017; Spalding et al., 2017). Importantly, ocean systems and species are valued for intrinsic, sociocultural, aesthetic, spiritual, recreational, and other reasons (Chan et al., 2012a).

Currently, a number of anthropogenic stressors threaten the relationships described above (reviewed in Jackson, 2010; Boyd, 2011; Halpern et al., 2012; Pendleton et al., 2016), and localized activities (e.g., pollution, sedimentation, overfishing, blast fishing) represent immediate and direct threats to marine ecosystems (Jackson et al., 2001; Thrush et al., 2004; Diaz and Rosenberg, 2008; Burke et al., 2011). Globally, climate change is emerging as the primary threat to marine social-ecological systems, with increases in ocean temperature, acidification, and sea-level rise increasingly affecting ocean ecosystems and vulnerable coastal communities (IPCC, 2019). As we confront a future of increasing global mean surface temperatures (Allen et al., 2018), increasing environmental variability (Sydeman et al., 2013), and increasing human populations (United Nations Department of Economic and Social Affairs Population Division, 2017), we anticipate amplification of these stressors and changes to relationships between human communities and marine ecosystems (Hoegh-Guldberg et al., 2018; IPCC, 2019).

A number of global initiatives converge in the importance of addressing these issues. The United Nations Sustainable Development Goals (SDGs) established 17 interlinked targets (United Nations, 2015; International Council for Science [ICSU], 2017) for achieving social and environmental well-being, including to "conserve and sustainably use the oceans, seas and marine resources for sustainable development" (SDG 14, "Life Below Water"). The Paris Agreement (United Nations Framework Convention on Climate Change [UNFCCC], 2015) includes goals related to the health of oceans and coastal communities such as enhancing adaptive capacity and resilience, and reducing damages to communities, in addition to focusing on climate change mitigation. The Convention on Biological Diversity (CBD) Aichi Biodiversity Targets (CBD, 2010) established 20 targets to improve the status of biodiversity, including increasing protected areas and sustainable fisheries, and enhancing climate resilience and sustainable ecosystem services. Several upcoming initiatives will include articles pursuant to healthy marine social-ecological systems, including the CBD post-2020 global biodiversity framework, and the United Nations Decade of Ocean Science for Sustainable Development (2021-2030). To achieve these initiatives in the context of projected climate and population trajectories, it is necessary to proactively identify research gaps and questions that, if addressed, would promote the greatest strides toward achieving a globally sustainable, just, and healthy future for marine social-ecological systems.

Ensuring healthy marine social-ecological systems in the future depends on how societies adapt and develop in the face of climate change. This will require broad, coordinated actions to reduce global emissions, protect existing natural carbon sinks (e.g., blue carbon), and increase the adaptive capacity of human 
communities and marine organisms to better cope with and recover from climate impacts. To accomplish these objectives, we need recommendations that consider ecological actions together with actions that affect policy, governance, and human behavior, as well as well-being, cultural diversity, and justice (Christie et al., 2003; Hallegatte and Mach, 2016; Wyborn et al., 2016; Claudet et al., 2020). In order for management to be proactive, rather than reactive, we need to understand what we need to know well in advance of the time it is needed.

To develop more integrative and proactive solutions, we engaged a diverse international and cross-sector team in a series of exercises to identify research questions and collaborations needed to rapidly promote sustainable and just marine socialecological relationships, given current projections on climate change and human demographics. Our team sought to provide diverse perspectives on what kinds of knowledge could lead to feasible actions, and to better choices among possible solutions. This process included a retrospective analysis of the major events over the last 60 years that have shaped today's marine socialecological systems, as well as identification of unanticipated events or synergisms that lead to substantial change in marine ecosystems directly, or indirectly, by driving change in human behavior (Duarte, 2014). We present results from these efforts first as they help frame the questions. We then present 9 priority research areas and 46 research questions that, if answered now, could transform current approaches to marine sustainability. We then provide further detail on eight questions consistently identified as critically important and currently unaddressed.

\section{MATERIALS AND METHODS}

The methods we used in this study are drawn from transdisciplinary research, which aims to "produce new knowledge by integrating different scientific and extra-scientific insights [with the goal of contributing] to both societal and scientific progress" (Jahn and Keil, 2015). This approach is well suited for complex problems with high uncertainty, multiple stakeholders, and diverse decision-making contexts. Transdisciplinary research groups typically benefit from a broad inclusion of worldviews, skills, and experience (Lynch et al., 2015). To this end, we assembled an international team with experience in investigative journalism, faith and secular community engagement, big data, art, indigenous knowledge, law and policy, climate change, marine ecology, fluid and geochemical modeling, political economy, public communication, conservation planning, and conservation psychology. The team (including coauthors) included representatives from academia, different levels of government, and the non-profit and private sectors.

Participants were presented with the orienting question, "If we were managing oceans in 2050 and looking back, what science, primary, or synthetic, would wish we had invested in today?" We assumed an increase of $1.5^{\circ} \mathrm{C}$ in global mean surface temperature by 2050 (Allen et al., 2018), and population of 9.8 billion by 2050 (United Nations Department of Economic and Social Affairs Population Division, 2017). Several activities were undertaken to create joint understanding of the sustainability problem to be addressed, and to collaboratively define specific research questions (Lang et al., 2012; Bengston, 2018).

First, we engaged in a retrospective analysis of major events over the last 60 years that have shaped today's marine socialecological systems. This technique (i.e., looking back twice as far as you look forward) is used to identify past trends and disruptions that could help illuminate the influences that current actions may have on the future (Saffo, 2007) and can provide guidance for future scenario planning by increasing idea generation (Rollier and Turner, 1994). We engaged in structured brainstorming of events, developments, and trends across the areas of society, technology, environment, economy, and politics that have affected oceans, and society's relationship to coasts and oceans. Although not exhaustive, this reflective process highlighted the role of technological advances, politics, and disaster as key drivers of major changes in ocean condition and health in the past 60 years. Results of this exercise are presented.

Next, small group and plenary exercises were designed to promote new opportunities for engagement and discourse and draw out diverse perspectives, to maximize the potential of group wisdom while reducing common pitfalls (Gregory et al., 2012). Kantor's Four-Player Model (2012) from family psychology was used to purposefully move individuals through different modes of communication to increase self-awareness of biases and default roles in group conversation. We then used scenario planning and a modified form of causal layered analysis (CLA; Inayatullah, 2003) to explore four alternative futures (Bengston, 2018), delineated by two axes: social connection (from fragmented to connected) and environmental health (from collapsed to sustained) (Merrie et al., 2018; Supplementary Figure S1). Participants discussed four future scenarios which were based in part on the shared socio-economic pathways (SSPs) developed for climate change research (O’Neill et al., 2017). We used CLA to explore underlying patterns and root causes that could lead to each alternative future. The scenarios were then used as a basis for discussion of research needs and opportunities.

Finally, we used a modified Delphi technique (Boulkedid et al., 2011; Mukherjee et al., 2015) to derive a list of priority research questions. We conducted three rounds of question generation and refinement consisting of a physical meeting and two iterative remote evaluations. The first round consisted of a 2-day physical meeting in which participants were engaged in question generation and refinement. We asked participants to focus on novel questions that were not already part of an active research agenda they were aware of, and which, if answered, could transform ocean management for the new realities of climate change. A total of 111 questions were recorded anonymously. Prior to the conclusion of the physical meeting, participants worked in teams to rank questions in terms of feasibility and impact. The second round of engagement was conducted after the physical meeting. Participants were given additional time to reflect on the full list of questions and were asked to independently identify 10 research questions from the original list they considered most important and currently unaddressed. These exercises were combined to produce a semifinal list of questions. In the third round of review, we refined the list 
of questions to eliminate redundancies and improve clarity, resulting finally in the 46 questions presented here. We invited all participants to review and provide feedback on the final list of questions. We provide further detail for eight research questions consistently identified during the three rounds as having both high feasibility and impact toward achieving more sustainable and just marine social-ecological systems.

\section{RESULTS AND DISCUSSION}

\section{Retrospective Analysis: Recent Events Shaping Marine Social-Ecological Systems}

Our reflective process on the historical trends, events, and developments that have led to the present state of marine socialecological systems highlighted the role of technology (e.g., the invention of plastics), politics (e.g., United Nations Convention on the Law of the Sea), and disaster (e.g., collapse of the Peruvian anchoveta fishery) as key drivers of major changes in ocean condition and health over the past 60 years (Figure 1 and Supplementary Table S1). While not exhaustive, the resulting perspective contributes toward a broader understanding of the processes that have shaped our current reality.

In addition to identifying steady pressures that drove change, we also identified a number of transformational events that were not widely anticipated but radically shifted behavior, politics, and perception around use and management of the marine environment (Figure 1 and Supplementary Table S1). Some of these events were the effect of sustained global processes (e.g., pollution, oil mining) or purposeful engagement (e.g., the movie Jaws). Others were sudden and relatively local, yet had far-reaching effects.

For example, the BP Deepwater Horizon oil spill in the Gulf of Mexico in April 2010 affected over 650 miles of Gulf coast habitats in a highly productive ecosystem, and resulted in major environmental, economic, and health damages (Graham et al., 2011). Among the unintended consequences associated with this event, Gulf oyster populations, which once were some of the best remaining in the world (Beck et al., 2011), were reduced 90\% following the spill, but not by oil. Rather, they were decimated by major freshwater releases in southeastern Louisiana motivated by the mistaken assumption that releases from the Mississippi basin would "push" and keep oil offshore. Further, demand for unaffected oysters and overfishing has contributed to the collapse or near-collapse of oyster fisheries and has led to major social change in places such as Apalachicola and Cedar Key, FL.

Another example is the 1956 outbreak of disease in Minamata, Japan, which eventually led to the diagnosis of over 2200 individuals with Minamata disease (methylmercury poisoning), shaped national and international policy on mercury pollution in marine systems, and led to widespread research and public health messaging on the consumption of affected marine organisms in which mercury bioaccumulates (e.g., shellfish, tuna). This event was preceded by more than 30 years of wastewater discharge containing methylmercury into Minamata
Bay. However, despite conclusive findings by 1959, wastewater discharge was not limited until a second outbreak of Minamata disease in 1965. Due to the study of affected individuals it is now well-understood that the bioaccumulation of high levels of mercury due to consumption of affected seafood led to neurological damage in patients, as well as health disorders in unborn children (Harada, 1995). The Minamata disaster had broad and long-lasting consequences. The public campaigns in response to the Minamata disaster are argued to have contributed to the post-WWII democratization of Japan (George, 2002). Research on mercury poisoning and bioaccumulation have resulted in national (e.g., Japan, Environmental Health and Safety Division [EHSD], 2013; US, Environmental Protection Agency [EPA], 2011) and international policies (Selin and Selin, 2006), and mercury warnings are prevalent in public health messaging worldwide.

While we may not be able to predict all such events, it is important to consider if and how we can build and restore necessary buffers that reduce the risk of adverse effects and enhance resilience ahead of time, as well as whether we can be more prepared during an event to opportunistically invest in strategies that reduce future risks to people and nature (see Q2.1, detailed below). This exercise also highlighted the critical role that mass-media, which developed during the 60 past years of our retrospective analysis, has played in the shaping of current social-ecological relationships. These influences include positive catalyzers, such as The Underwater World of Jacques Cousteau, which first brought the beauty of the underwater world into many homes, and the Blue Planet series, associated with the global movement to reduce plastic pollution. The documentary An Inconvenient Truth also raised public awareness of the dangers of climate change. On the negative side, however, the movie Jaws traumatized generations of humans and demonizing sharks, now threatened across the oceans, and Finding Nemo led to a global demand for clown fish in household aquaria that decimated the wild fish population along with their anemone host. Mass communication is likely to continue to be a major driver of change in human behaviors that affect marine ecosystems, likely in the form of social media or forms of mass communication yet to be developed, and require attention as powerful catalysts of change (see Q4.1, detailed below).

\section{Priority Research}

We identified 9 priority research areas and 46 research questions (Table 1). The priority research areas are: (1) ecological, individual, and cultural health; (2) crises as opportunities; (3) economics and financial incentives; (4) effective and inclusive communication; (5) ecological analyses; (6) governance; (7) technology and increased connectivity; (8) human behavioral change; and (9) food security. The questions we generated were predominantly multidisciplinary, highlighting that the potential for transformational change lies in meaningful engagement at the intersections of traditionally distinct disciplines and sectors. In this section, we detail eight questions consistently identified as high priority, providing a brief overview of current knowledge and potential impact of each. We refer readers to Table 1 to explore the full list of priority research questions. Highlighted 


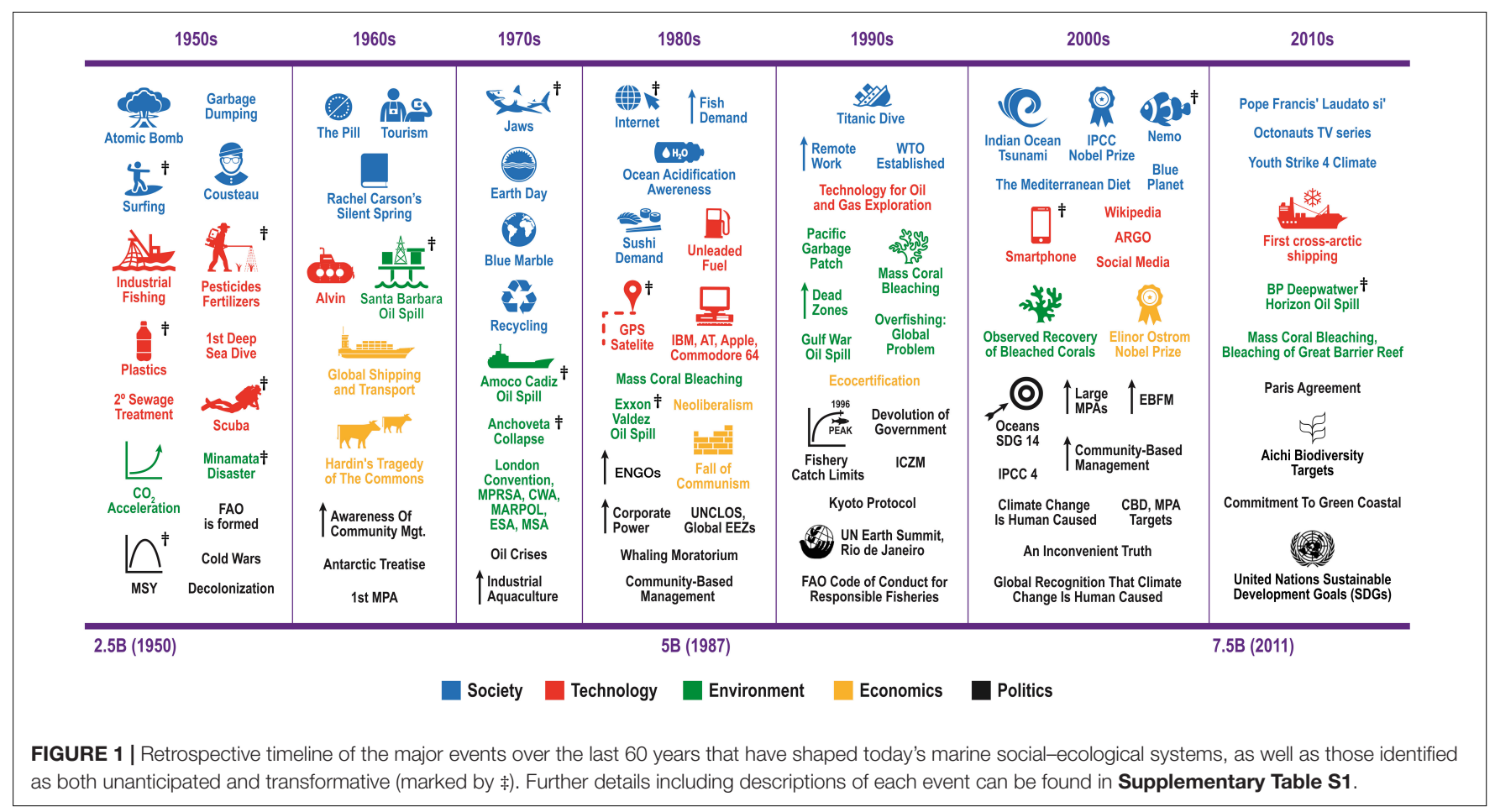

questions are labeled with reference numbers used in Table 1, corresponding to their research area.

What does a healthy ocean look like under different world views? What are the key components of equity that affect diverse coastal communities, and how do they vary? Which interventions, in what contexts, provide the most benefit for people and nature? (Q1.1)

While the CBD highlights the importance of equity among stakeholders in conservation practice (CBD, 2010, 2011), there is limited evidence on how and in what situations equity interventions influence ocean health and conversely, how conservation initiatives affect equity. Examining common ocean sustainability interventions through an equity lens could shift the way interventions are envisioned and applied. General findings show that community stakeholder engagement is important for the success of conservation initiatives (Giakoumi et al., 2018), and outcomes are highly dependent on processes for participation (Reed, 2008; Sterling et al., 2017). "Equity" is a multidimensional issue, and multiple frameworks exist that describe differences in types of equity and how they may interface with conservation initiatives (Klein et al., 2015; Montambault et al., 2018). Critical knowledge gaps include: (1) how equity dynamics (types of equity issues, e.g., access equity, gender equity, generational equity; Klein et al., 2015) vary across different social and ecological contexts; (2) how different types of equity and conservation interventions affect the well-being of individuals and coastal ecosystems (e.g., Cinner et al., 2012a; Gurney et al., 2014); (3) what kinds of interventions are both appropriate and provide the greatest benefit to people and nature in diverse contexts (e.g., Castilla et al., 1998; Gelcich et al., 2008, 2012, 2015; Lubchenco et al., 2016); and (4) how issues such as access or distributional equity are affected by shifts in climate (Badjeck et al., 2010; Cinner et al., 2012b). Additional research in this area may evaluate the effectiveness of increased collaboration between conservation groups and organizations concerned with toxins, maritime-based human trafficking, food sovereignty movements, waste management, climate justice, and faith-based organizations (e.g., McLeod and Palmer, 2015).

Are women's empowerment and increased engagement related to sustainable marine ecosystems and improved ocean management? If so, could the promotion of women's empowerment and engagement improve ocean health? (Q1.3)

A key dimension of health and well-being in marine socialecological systems is gender equity. Key research in this area includes whether and how gender equity relates to the long-term sustainable use and management of marine resources, as well as whether increased focus on gender equity promotes positive social and ecological consequences in coastal communities. Among the largest limitation in this research to date is the scarcity of gender disaggregated data across countries and domains (Monfort, 2015). Studies on the relationships between women's access to marine resources, participation in marine resource governance, and ocean health are limited (Leisher et al., 2016; Kleiber et al., 2017; Gallardo-Fernández and Saunders, 2018; McLeod et al., 2018; Quimby and Levine, 2018); however, findings from these studies are emerging as critical issues in marine social-ecological systems especially in the context of climate change. Recent global analyses estimate that women comprise $47 \%$ of the workforce engaged in fishing and post-harvest operations, including in nearshore fisheries, gleaning, aquaculture, processing, trading, and 
TABLE 1 | Nine priority research areas and 46 research questions for promoting healthy marine ecosystems and human communities.

\section{Ecological, individual, and cultural health}

1.1* What does a healthy ocean look like under different world views? What are the key components of equity that affect diverse coastal communities, and how do they vary? Which interventions, in what contexts, provide the most benefit for people and nature?

1.2 How do changes in marine food web structures and availability interact with human communities' ability to respond to change and manage cultural practices, identity, and nutrition?

1.3* Are women's empowerment and increased engagement related to sustainable marine ecosystems and improved ocean management? If so, could the promotion of women's empowerment and engagement improve ocean health?

1.4 What are the synergies between ecological, individual, and cultural health? e.g., Does increasing well-being and reducing income inequality lead to a healthier ocean?

1.5 What are the connections between ocean changes and social vulnerability? How will climate change affect dynamics/feedbacks between social and cultural systems? How can this inform and motivate social responses?

1.6 Are there different consequences for unanticipated and transformational events across social, ecological, and governance systems? How do different social, ecological, and governance systems vary in their capacity to respond to such events?

1.7 How do faith communities relate to food, nutrition, and family planning decisions?

\section{$2 \quad$ Crises as opportunities}

2.1* How do we use crises as opportunities to reduce future risks to people and nature?

2.2 Can we build resilience to unforeseeable events that have a major impact?

\section{Economics and financial incentives}

3.1 How do we encourage cross-sector collaborations (e.g., between science and social justice community) to quickly address gaps in research and implement associated recommendations?

3.2 What would it cost to fully restore all marine biodiversity, and what would the ROI be on that investment?

3.3 What are the most effective ways to scale-up positive interventions (e.g., mangroves could be completely restored within 20 years if we wanted to)?

3.4 Challenges of scale. How to effectively scale global issues to local solutions? How to merge local values and indicators people care about at the scale where they would be useful?

3.5 How will blue economic growth affect ocean health?

3.6 What are the global drivers of fish consumption (e.g., need vs. preference/luxury), and can alternative sources of protein shift this consumption pattern?

3.7 Which market-based vs. community-based economic instruments are most effective in shifting toward sustainability across diverse social and ecological contexts?

\section{$4 \quad$ Effective and inclusive communication}

4.1* Does media catalyze change in policies and actions that impact global ocean health, and if so, how?

4.2 How do different people/societies/cultures/sectors define an aspirational ocean future? Is there an emergent shared vision?

4.3 What are effective communication strategies to increase public support for ocean conservation and communicate issues to a broader range of people?

4.4 How does our language (the words we use) become a barrier to progress? How do we unveil biases that creep into the words we use? How does fear of saying the wrong thing impede engagement?

\section{$5 \quad$ Ecological analyses}

5.1 At what point (and where) will there be tipping points in ocean circulation and what are projected local and global implications? How will climate tipping points affect ocean health and people?

5.2 What does the possible ocean future look like? What are the range of possible outcomes?

5.3 What are the future uses of the ocean, and what will characterize our relationship with the oceans in 2050? (e.g., 1950-1980: Extractive, 1980-2010: Reactive, 2010-2050: Constructive? Reciprocal? Other?)?

$5.4 \quad$ What have been the consequences of massive habitat loss in the oceans?

5.5 What will be the impacts of climate change on marine life and what adaptation options are possible?

5.6 What is the source and fate of plastics in oceans?

5.7 What would happen if we met the Paris targets, Aichi targets, and the SDG-14 targets?

5.8 Under what contexts do conservation interventions succeed? What are the factors of success? How can we improve the data collected through conservation initiatives?

\section{$6 \quad$ Governance}

6.1* In what ways do different governance systems (formal and informal) respond and adapt to change? Which governance systems, under what conditions, have resulted in tangible changes in ocean management? What are the most effective structures of governance for promoting community health, resilience, and sustainable ecosystems? (Global, state, local?)

6.2 What are the implications of privatizing the entire ocean (e.g., via rights-based management)?

6.3 Who are the decision makers taking action to improve ocean health? How effective are they?

6.4 What are countries doing in terms of: investment, use, and protection of marine resources both within and outside of EEZs? 
TABLE 1 | Continued

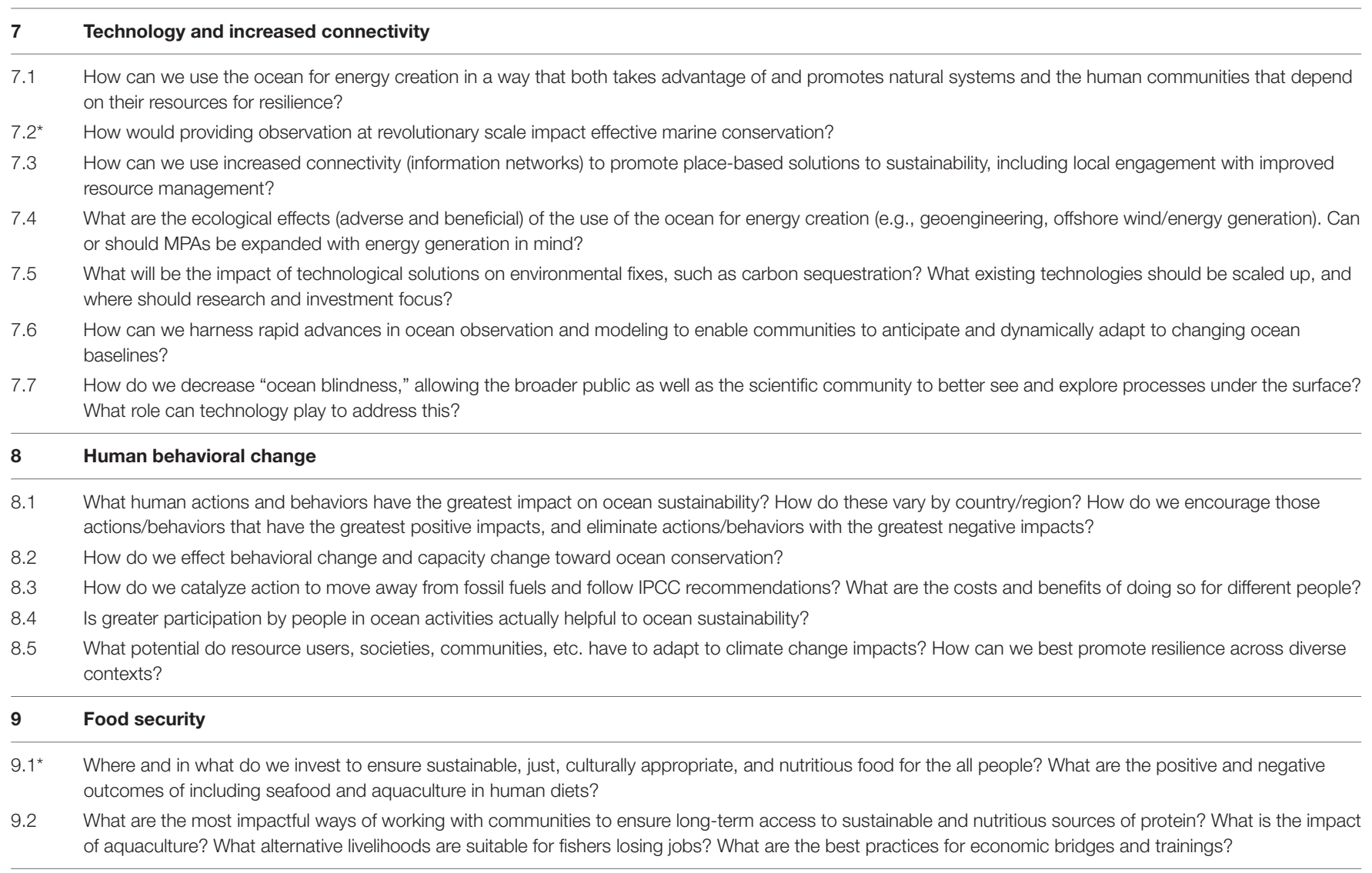

The eight questions identified as particularly impactful and feasible are marked with an asterisk and detailed further in the section "Results and Discussion."

financing of fisheries (Monfort, 2015; Kleiber et al., 2015). However, the degree and effects of women's participation, or representation, in fisheries management have not been well described. Many resource users, including women, have ecological and traditional knowledge that can improve resource management; excluding women from management decisionmaking likely leads to managing with incomplete knowledge of the resource system and users (Agarwal, 2009; McLeod et al., 2018). In addition, greater participation by women in the decision-making process has been shown to increase compliance (Agarwal, 2009) and has the potential to support increased equity among resource users (Gallardo-Fernández and Saunders, 2018). Critically, there are increasing risks to health and livelihood among disenfranchised groups (often including women), as climate change increases the rate and intensity of natural disasters (Morioka, 2016; McLeod et al., 2018; Sorensen et al., 2018). Studies aimed at better understanding the role of women, as well as other disenfranchised groups, in sustainable resource management, as well as how to best promote more inclusive management will provide necessary insight toward the co-development of environmental and social strategies moving forward.

How do we use crises as opportunities to reduce future risks to people and nature? (Q2.1)
Crises often present opportunities to transform systems of resource use and management (Folke et al., 2010). Critical coastal management decisions are made during the phases of response, recovery, planning, and mitigation that follow crises, and these decisions can result in permanent changes in policy or agency structure. For example, the formation of the EPA and passage of the RESTORE Act followed pollution crises of considerable magnitude in the United States during the 1960s. Following such events, long-standing policies on risk and coastal management are often re-considered, and millions to billions of dollars are spent on recovery, rebuilding, and restoration. Rapid decision making can have profoundly negative or positive impacts on the long-term resilience of coastal and marine ecosystems and the people who depend on them. For example, while Hurricane Sandy inspired increased interest in improving coastal resilience, only $\sim 1 \%$ of recovery funding was used for building natural coastal resilience (e.g., wetland restoration; Barbier, 2015), representing a missed opportunity. By contrast, the Indian Ocean Tsunami of 2004 provided evidence of the protective role of mangroves against extreme events impacting on coastal areas, leading to major restoration efforts in the region (Barbier, 2006). Research shows natural, "green," solutions achieve a consistently greater cost-benefit ratio compared to most gray infrastructure solutions (Reguero et al., 2018) and can provide a significant 
reduction in total economic risk (Narayan et al., 2017; Beck et al., 2018). The recovery phase is an important period to provide sound scientific advice and achieve long-lasting progress toward increased resilience and sustainability. However, doing so requires a vision for the changes we would like to see in policy and practice, strong collaborations that can be rapidly enacted post-event, and identification of appropriate lessons that can be applied to increase the resilience of coastal social-ecosystems.

Does media catalyze change in policies and actions that impact global ocean health, and if so, how? (Q4.1)

The role of advertising in driving behavioral change is well researched (reviewed in Stewart et al., 2002). However, the effective use of media to promote environmental action is less understood. For instance, why did a video of a turtle with a straw embedded in its nose inspire widespread public action to ban plastic straws, while many other information campaigns elicit little response? Environmental action may relate in some ways to well-researched effects such as priming intensity (RoskosEwoldsen et al., 2009), interpersonal communication following media consumption (ibid), or trust in the media source (Stewart et al., 2002). However, it is also possible that environmental action results from different kinds or subsets of communication strategies than those that inspire consumptive or political action. Marketing professionals integrate findings from the field of psychology to develop advertisements (e.g., to sell toothpaste). How is the psychology of motivating environmental behavior and policy change, specifically in relation to the ocean, different from that of marketing products? While many theories have been proposed in the field of environmental psychology, no definitive answers have been found regarding consistent drivers of pro-environmental behavior (Kollmuss and Agyeman, 2002). The "information deficit" model, which assumes environmental education will lead directly to environmental action, has been demonstrated repeatedly to be ineffective at generating widespread behavior change, but it remains a dominant strategy used in public campaigns by NGOs and governments (ibid). Research into social behavioral drivers has shown that perceived social norms can influence environmental behavior; for instance, Schultz et al. (2007) found that consumers changed their electricity consumption when they received normative feedback about how their consumption compared to that of their neighbors. Finally, in the same way that the broad integration of television in the 1950s and '60s ushered in a new era of sharing news, entertainment, and educational programming, the upheaval in social and other media now could present an opportunity for immediate action, transforming the way scientists, practitioners, and the general public collaborate. However, competition for the attention of global audiences may lead media to spin headlines regarding research reports on the status of the ocean, consolidating a negative perception beyond that supported by evidence, and drawing the public to inaction (Duarte et al., 2014). How can these new forms of media be most effectively used to inspire positive environmental action?
How do different people/societies/cultures/sectors define an aspirational ocean future? Is there an emergent shared vision? (Q4.2)

A quantitative analysis of how cultural and societal factors affect "visions" for a healthy future ocean would contribute toward culturally relevant conservation strategies and metrics for measuring conservation success. Research on values of coastal ecosystems has been criticized for prioritizing economic values and for ignoring intrinsic and cultural values as motivation for conservation action (Chan et al., 2012b). For example, stewardship of nature is valued in many religions, and may be well-aligned with conservation objectives (Bhagwat et al., 2011). Sacred natural sites are often affiliated with increased endemic biodiversity, old growth forests, and rare species (Dudley et al., 2010). While diverse cultural values and practices may lead to conservation outcomes, they may differ substantially from mainstream conservation practices and may not be recognized by conservation initiatives or higher levels of governance (Govan and Jupiter, 2013; Jupiter, 2017). Once these dimensions are better understood, groups spanning multiple scales and contexts (e.g., collaborations among governments, communities, conservation groups, social well-being, and sustainable development organizations) could work to define best practices for promoting social and ecological well-being within the context of a particular worldview. On an international level, this could lead to developing policy and support for diverse solutions. This research could also inform future scenarios used by groups such as IPCC (e.g., Rogelj et al., 2018) that do not currently include diverse views of future human-ecological relationships.

In what ways do different governance systems (formal and informal) respond and adapt to change? Which governance systems, under what conditions, have resulted in tangible changes in ocean management? What are the most effective structures of governance for promoting community health, resilience, and sustainable ecosystems? (Global, state, local?) (Q6.1)

Various studies have examined the efficacy of fisheries management regimes, including impacts and outcomes of marine protected areas (MPAs), Territorial Use Rights Fisheries (TURFs), catch shares or catch limits, co-management, and gear restrictions (e.g., Halpern, 2003; Mascia et al., 2010; Cinner et al., 2012a; Edgar et al., 2014; d’Armengol et al., 2018; Gelcich et al., 2019). However, this research has rarely considered the question of how different governance structures respond and adapt to significant ecological change. What systems of governance are most effective for sustainable management of fisheries and other ocean-based resources across ecological and social contexts? Answering these questions requires identifying the governance context and strategies that have been employed in the face of significant ecological changes in the past to explore how different governing and management systems have, or have not, been resilient to fundamental changes due to past trends and events. 
How would providing observation at revolutionary scale impact effective marine conservation? (Q7.2)

Many current ocean observation systems are sporadic and aimed at individual products. Even examples of large efforts sustained by governments (e.g., fisheries trawl surveys stretching over 50 years) are episodic, conducting surveys one or two times a year, in heavily fished areas, at a finite number of points. Such constraints impose management and conservation challenges that could be reduced with observing technology. However, advances in ocean robotics, emerging global efforts in observation (e.g., the Global Ocean Observation System, Lindstrom et al., 2012), and the development of several national and international initiatives (including the UN Decade on Ocean Science) highlight the present as a critical moment for the development and use of increased monitoring for scientific discovery, environmental analysis, and informing policy across scales (Visbeck, 2018; Claudet et al., 2020). The impact of a big-data approach to ocean observation is emerging through products recently derived from access to Automatic Identification System (AIS). For the first time, these have allowed the mapping of global fishing activity and quantification of use of the High Seas ${ }^{1}$ (McCauley et al., 2016), among other applications. The data generated by this technology, however, is accessible only by fee, and while massive in scale it must be expanded, as it currently encompasses only $50-70 \%$ of the global fishing fleet. More pervasive ocean observation could permit more dynamic, responsive, and predictive classification of MPAs, to support movement of protected areas relative to habitat, migratory species, climate change, and other requirements (e.g., Tommasi et al., 2017). Long-term and high-resolution datasets can be used globally to better understand patterns and processes in the ocean, and to promote sustainable management of resources, including in response to shifts in the phenology of marine systems (Hazen et al., 2018; Hays et al., 2019). They also can improve evaluation of ongoing efforts by providing metadata and documentation on project design and metrics of success and failure, as well as facilitate the development of predictive models for assessing climate change impacts at ecologically relevant scales (Rilov et al., 2019). Furthermore, greater access to information on the use of open oceans and exclusive economic zone intrusions will help to quantify and manage use. The potential payoff of new ocean observing capacity stretches beyond these examples to, more generally, anticipatory and real-time rather than reactionary decision making across a range of marine resource issues (Maxwell et al., 2015).

Where and in what do we invest to ensure sustainable, just, culturally appropriate, and nutritious food for the all people? What are the positive and negative outcomes of including seafood and aquaculture in human diets? (Q9.1)

As we work toward a sustainable and just future, meeting the nutrition demands for a rapidly growing global population (United Nations Department of Economic and Social Affairs Population Division, 2017) will require culturally appropriate

${ }^{1}$ globalfishingwatch.org solutions that are robust to increasing environmental and economic shocks to food systems (Cottrell et al., 2019). Achieving this goal requires better understanding of the ecological and social linkages between food systems to properly assess synergies, trade-offs, and vulnerabilities (Halpern et al., 2019). Further research is required to assess the ecological and human health trade-offs associated with different food sources and diets (Tilman and Clark, 2014; Davis et al., 2016), as well as the costs and benefits of increased trade across different regions and cultures (Puma et al., 2015), including issues of justice and equity in the export of luxury protein (e.g., shrimp/prawns) from proteindeficient to protein-rich societies. In addition to traditional agricultural crops, livestock, and fisheries, marine aquaculture is increasing, and has enormous potential to increase access to nutritionally rich seafood and create jobs while modulating the demand that drives issues such as overfishing (e.g., Gentry et al., 2017). However, ecological consequences must be accounted for in order for aquaculture to be sustainable (e.g., Froehlich et al., 2018a). Devising pathways for sustainable aquaculture production and evaluating the limiting factors is fundamental to manage expectations on the role that aquaculture should play in sustainably delivering healthy food contributing to the well-being of a growing human population. Other novel alternatives include the development of cellular agriculture ("lab meat") (Stephens et al., 2018) and seafood ("clean seafood"). All solutions, whether traditional or novel, have different potential for innovation and adoption, and dynamics between production mechanisms, demand, equity, trade pathways, and ecological relationships require further research.

\section{Discussion of the Process and Findings}

While horizon scanning exercises have been conducted for global conservation issues (e.g., Sutherland et al., 2018), few have specifically considered issues facing marine social-ecological systems. Furthermore, those horizon-scanning exercises were focused on current research needs rather than the research needed to prepare for future pressures, anticipated and not. Those that have focused on the marine environment (Heip et al., 2011; Fissel et al., 2012; Parsons et al., 2014; Rudd, 2014) have included few, if any, contributors outside the environmental sciences. In this study, we engaged a broad set of experts to identify critical research needed to radically improve human wellbeing and ecosystem health over the next 30 plus years. This likely contributed to the more multidisciplinary nature of the questions and themes than have arisen in traditional horizon scanning exercises, and a greater balance between the focus on natural and social sciences in framing and developing the questions. However, we note that other studies ( $i b i d$ ), despite engaging less diverse groups, have identified social-ecological questions as priority research areas. We also recognize that our efforts toward diverse inclusion could have been broader, e.g., by engaging indigenous peoples and greater geographic diversity, including more representatives of developing countries. The incorporation of these perspectives would generate additional important 
questions, and we hope that future efforts will continue to improve in this regard.

The primary question posed to the working group as well as preliminary exercises oriented our group toward issues contextualized by climate change. We believe this was an appropriate and realistic contextualization of scientific questions aimed at long-term impacts across social and ecological boundaries. However, this future-focused lens likely minimized questions that may have focused on tensions between immediate processes and needs. Additionally, while our focus was on marine systems, many of the research questions identified are likely relevant in other types of social-ecological systems.

Accomplishing global targets for climate change mitigation, marine conservation, human well-being, and sustainable development (e.g., Paris Agreement, United Nations SDGs, Aichi Biodiversity Targets) requires multidisciplinary and crosssector research and collaboration (Hallegatte and Mach, 2016; Claudet et al., 2020). The list of priority research questions identified here would, if addressed, contribute important research toward achieving these global initiatives far into the future. For instance, priority research area 1 ("Ecological, individual, and cultural health") includes questions related to SDG-2 (zero hunger), SDG-3 (good health and wellbeing), SDG-10 (reduced inequalities), and SDG-13 (climate action), as well as SDG-14 (ocean sustainability) (United Nations, 2015). Many of our questions also align with the Aichi Biodiversity Targets (CBD, 2010), especially Targets 4, 6, 7, 11, and 14-16, and with Articles 6-7 of the Paris Agreement (United Nations Framework Convention on Climate Change [UNFCCC], 2015). Several research questions, especially those in priority research areas 3 ("Economics and financial incentives") and 7 ("Technology and increased connectivity") would also contribute valuable information toward evaluating and implementing the World Bank's "Blue Economy" initiative (World Bank and United Nations Department of Economic and Social Affairs, 2017), as well as SDG-7 (United Nations, 2015). Finally, many identified questions are well-aligned to the United Nations Decade of Ocean Science for Sustainable Development (2021-2030). In addition to their contribution to these initiatives, all questions identified in this study strive toward a common goal of achieving the best possible ocean future.

We firmly support the continuation of such cross-sector collaborations, both in determining research objectives, as well as in carrying out studies and working toward solutions. In fact, global initiatives such as the SDGs provide a framework to interface across organizations, including those working on issues of justice, but who hold to a more anthropocentric worldview. However, the current infrastructure of funding and institutional support for collaborations across institutions and sectors is lacking. Supporting cross-sector collaborations among management organizations, non-profits, and academic institutions requires increased institutional support. Particularly useful mechanisms include increased support for boundary organizations, increased funding opportunities for coproduction (for example, those that currently require conservation organizations to work with development agencies in proposals), increased recognition for participation in coproduction groups (e.g., in academic tenure review), increased training in effective coproduction, and building the cultural competency to work across sectors (Reich and Reich, 2006; Cook et al., 2013; Beier et al., 2017). We emphasize that cross-sector collaborations are fundamental to tackling interlinked global issues at relevant scales and time-course.

We believe the questions presented here are exemplary of the kinds of cross-sector research agendas required to confront the challenges facing marine social-ecological systems. We hope that funding organizations and research groups will take up these questions as priorities as we move together toward a healthy and just future for ourselves and our oceans.

\section{AUTHOR CONTRIBUTIONS}

JM, HP, BH, EM, MB, and CK designed the workshop. WF, $\mathrm{JM}, \mathrm{BH}, \mathrm{EM}$, and $\mathrm{MB}$ carried out the analysis and created the publication draft. All authors (except one) participated in the working group meeting and question generation. All authors reviewed the manuscript and participated in the refinement of questions and/or revisions to the manuscript.

\section{FUNDING}

This work was supported by the David and Lucile Packard Foundation, Grant No. 2018-67289 to The Nature Conservancy on behalf of the Science for Nature and People Partnership (SNAPP). WF was supported by a NatureNet Postdoctoral Fellowship issued by The Nature Conservancy.

\section{ACKNOWLEDGMENTS}

This research was conducted by the Ocean Futures expert working group supported by the Science for Nature and People Partnership (SNAPP), a collaboration of The Nature Conservancy, the Wildlife Conservation Society, and the National Center for Ecological Analysis and Synthesis (NCEAS) at the University of California, Santa Barbara. We are grateful to John Amos, William C. Cheung, Emily S. Darling, Christina C. Hicks, Jason Patlis, Sarah Sayeed, and Charles A. Stock for their thoughtful contributions during the working group meeting.

\section{SUPPLEMENTARY MATERIAL}

The Supplementary Material for this article can be found online at: https://www.frontiersin.org/articles/10.3389/fmars. 2020.00005/full\#supplementary-material 


\section{REFERENCES}

Agarwal, B. (2009). Gender and forest conservation: the impact of women's participation in community forest governance. Ecol. Econ. 68, 2785-2799. doi: 10.1016/j.ecolecon.2009.04.025

Allen, M. R., Dube, O. P., Solecki, W., Aragón-Durand, F., Cramer, W., Humphreys, S., et al. (2018). "Framing and context," in Global Warming of 1.5C. An IPCC Special Report on the Impacts of Global Warming of 1.5C Above PreIndustrial Levels And Related Global Greenhouse Gas Emission Pathways, in The Context Of Strengthening the Global Response to the Threat Of Climate Change, Sustainable, eds V. Masson-Delmotte, P. Zhai, H. O. Pörtner, D. Roberts, J. Skea, P. Shukla, et al. (Geneva: IPCC).

Badjeck, M.-C., Allison, E. H., Halls, A. S., and Dulvy, N. K. (2010). Impacts of climate variability and change on fishery-based livelihoods. Mar. Policy 34, 375-383. doi: 10.1016/j.jtherbio.2019.06.001

Barbier, E. B. (2006). Natural barriers to natural disasters: replanting mangroves after the tsunami. Front. Ecol. Environ. 4, 124-131. doi: 10.1890/15409295(2006)004[0124:NBTNDR]2.0.CO;2

Barbier, E. B. (2015). Policy: hurricane katrina's lessons for the world. Nat. News 524:285.

Beck, M. W., Brumbaugh, R. D., Airoldi, L., Carranza, A., Coen, L. D., Crawford, C., et al. (2011). Oyster reefs at risk and recommendations for conservation, restoration, and management. Bioscience 61, 107-116. doi: 10.1525/bio.2011. 61.2 .5

Beck, M. W., Losada, I. J., Menéndez, P., Reguero, B. G., Díaz-Simal, P., and Fernández, F. (2018). The global flood protection savings provided by coral reefs. Nat. Commun. 9:2186. doi: 10.1038/s41467-018-04568-z

Beier, P., Hansen, L. J., Helbrecht, L., and Behar, D. (2017). A how-to guide for coproduction of actionable science. Conserv. Lett. 10, 288-296. doi: 10.1111/ conl. 12300

Béné, C., Arthur, R., Norbury, H., Allison, E. H., Beveridge, M., Bush, S., et al. (2016). Contribution of fisheries and aquaculture to food security and poverty reduction: assessing the current evidence. World Dev. 79, 177-196. doi: 10. 1016/j.worlddev.2015.11.007

Bengston, D. N. (2018). Futures research methods and applications in natural resources. Soc. Nat. Resour. 32, 1099-1113. doi: 10.1080/08941920.2018. 1547852

Bhagwat, S. A., Dudley, N., and Harrop, S. R. (2011). Religious following in biodiversity hotspots: challenges and opportunities for conservation and development. Conserv. Lett. 4, 234-240. doi: 10.1111/j.1755-263x.2011.00169.x

Boulkedid, R., Abdoul, H., Loustau, M., Sibony, O., and Alberti, C. (2011). Using and reporting the Delphi method for selecting healthcare quality indicators: a systematic review. PLoS One 6:e20476. doi: 10.1371/journal.pone.0020476

Boyd, P. W. (2011). Beyond ocean acidification. Nat. Geosci. 4:273. doi: 10.1038/ ngeo 1150

Burke, L., Reytar, K., Spalding, M., and Perry, A. (2011). Reefs at Risk Revisited. Washington, D.C: WRI.

Castilla, J. C., Manriquez, P., Alvarado, J., Rosson, A., Pino, C., Espoz, C., et al. (1998). Artisanal "caletas" as units of production and co-managers of benthic invertebrates in Chile. Can. Special Public. Fish. Aquat. Sci. 125, $407-413$.

CBD, (2010). "The strategic plan for biodiversity 2011-2020 and the aichi biodiversity targets," in Proceedings of the UNEP Conference on the Parties to the Convention on Biological Diversity, Nairobi.

CBD, (2011). Nagoya Protocol on Access to Genetic Resources and the Fair and Equitable Sharing of Benefits Arising from their Utilization to the Convention on Biological Diversity. Secretariat of the Convention on Biological Diversity. Nairobi: United Nations Environmental Programme.

Chan, K. M. A., Guerry, A. D., Balvanera, P., Klain, S., Satterfield, T., Basurto, X., et al. (2012a). Where are cultural and social in ecosystem services? a framework for constructive engagement. Bioscience 62, 744-756. doi: 10.1525/bio.2012. 62.8 .7

Chan, K. M. A., Satterfield, T., and Goldstein, J. (2012b). Rethinking ecosystem services to better address and navigate cultural values. Ecol. Econ. 74, 8-18. doi: 10.1016/j.ecolecon.2011.11.011

Christie, P., McCay, B. J., Miller, M. L., Lowe, C., White, A. T., Stoffle, R. W., et al. (2003). Toward developing a complete understanding: a social science research agenda for marine protected areas. Fisheries 28, 22-26.
Cinner, J. E., McClanahan, T. R., Graham, N. A., Daw, T. M., Maina, J., Stead, S. M., et al. (2012a). Vulnerability of coastal communities to key impacts of climate change on coral reef fisheries. Glob. Environ. Chang. 22, 12-20. doi: 10.1016/j.gloenvcha.2011.09.018

Cinner, J. E., McClanahan, T. R., MacNeil, M. A., Graham, N. A. J., Daw, T. M., Mukminin, A., et al. (2012b). Comanagement of coral reef social-ecological systems. Proc. Natl. Acad. Sci. U.S.A. 109, 5219-5222. doi: 10.1073/pnas. 1121215109

Claudet, J., Bopp, L., Cheung, W. W. L., Devillers, R., Escobar-Briones, E., Haugan, P., et al. (2020). A roadmap for using the UN Decade of Ocean Science for sustainable development in support of science, policy, and action. One Earth 2, 1-9. doi: 10.1016/j.oneear.2019.10.012

Cook, C. N., Mascia, M. B., Schwartz, M. W., Possingham, H. P., and Fuller, R. A. (2013). Achieving conservation science that bridges the knowledge-action boundary. Conserv. Biol. 27, 669-678. doi: 10.1111/cobi.12050

Cottrell, R. S., Nash, K. L., Halpern, B. S., Remenyi, T. A., Corney, S. P., Fleming, A., et al. (2019). Food production shocks across land and sea. Nat. Sustainabil. 2, 130-137.

d'Armengol, L., Castillo, M. P., Ruiz-Mallén, I., and Corbera, E. (2018). A systematic review of co-managed small-scale fisheries: social diversity and adaptive management improve outcomes. Glob. Environ. Chang. 52, 212-225. doi: 10.1016/j.gloenvcha.2018.07.009

Davis, K. F., Gephart, J. A., Emery, K. A., Leach, A. M., Galloway, J. N., and D'Odorico, P. (2016). Meeting future food demand with current agricultural resources. Glob. Environ. Chang. 39, 125-132. doi: 10.1016/j.gloenvcha.2016. 05.004

Diaz, R. J., and Rosenberg, R. (2008). Spreading dead zones and consequences for marine ecosystems. Science 321, 926-929. doi: 10.1126/science.1156401

Duarte, C., and Agustí, S. (1998). The CO2 balance of unproductive aquatic ecosystems. Science 281, 234-236. doi: 10.1126/science.281.5374.234

Duarte, C. M. (2014). Global change and the future ocean: a grand challenge for marine sciences. Front. Mar. Sci. 1:63. doi: 10.1038/s41586-018-0563-7

Duarte, C. M., Fulweiler, R. W., Lovelock, C. E., Martinetto, P., Saunders, M. I., Pandolfi, J. M., et al. (2014). Reconsidering ocean calamities. Bioscience 65, 130-139. doi: 10.1093/biosci/biu198

Duarte, C. M., Losada, I. J., Hendriks, I. E., Mazarrasa, I., and Marbà, N. (2013). The role of coastal plant communities for climate change mitigation and adaptation. Nat. Clim. Chang. 3, 961-968. doi: 10.1371/journal.pone. 0044727

Dudley, N., Bhagwat, S., Higgins-Zogib, L., Lassen, B., Verschuuren, B., and Wild, R. (2010). "Conservation of biodiversity in sacred natural sites in Asia and Africa: a review of the scientific literature," in Sacred Natural Sites: Conserving Nature and Culture, eds B. Verschuuren, R. Wild, J. McNeely, and G. Oviedo, (London: Earthscan), 19-32.

Edgar, G. J., Stuart-Smith, R. D., Willis, T. J., Kininmonth, S., Baker, S. C., Banks, S., et al. (2014). Global conservation outcomes depend on marine protected areas with five key features. Nature 506, 216-220. doi: 10.1038/nature13022

Environmental Health and Safety Division [EHSD] (2013). Lessons from Minamata Disease and Mercury Management in Japan. Pleasant Hill, CA: Ministry of the Environment.

Environmental Protection Agency [EPA] (2011). National Emissions Standards for Hazardous Air Pollutants from Coal And Oil-Fired Electric Utility Steam Generating Units And Standards Of Performance for Fossil-Fuel-Fired Electric Utility, Industrial-Commercial-Institutional, and Small Industrial-CommercialInstitutional Steam Generating Units. Washington, DC: EPA.

FAO (2012). The State of World Fisheries and Aquaculture. Rome: Food and Agriculture Organization of the United Nations.

FAO (2018). The State of World Fisheries and Aquaculture 2018 - Meeting the Sustainable Development Goals. Rome: Food and Agriculture Organization of the United Nations.

Fissel, D., Group, C., Babin, M., Bachmayer, R., Dewailly, E., Gillis, K. M., et al. (2012). 40 Priority research questions for ocean science in Canada.

Folke, C., Carpenter, S., Walker, B., Scheffer, M., Chapin, T., and Rockström, J. (2010). Resilience thinking: integrating resilience, adaptability and transformability. Ecol. Soc. 15:20.

Froehlich, H. E., Gentry, R. R., and Halpern, B. S. (2018a). Global change in marine aquaculture production potential under climate change. Nat. Ecol. Evol. 2, 1745-1750. doi: 10.1038/s41559-018-0669-1 
Froehlich, H. E., Jacobsen, N. S., Essington, T. E., Clavelle, T., and Halpern, B. S. (2018b). Avoiding the ecological limits of forage fish for fed aquaculture. Nat. Sustainabil. 1, 298-303. doi: 10.1038/s41893-018-0077-1

Gallardo-Fernández, G. L., and Saunders, F. (2018). "Before we asked for permission, now we only give notice": women's entrance into artisanal fisheries in Chile. Mar. Stud. 17, 177-188. doi: 10.1007/s40152-018-0110-z

Gelcich, S., Fernández, M., Godoy, N., Canepa, A., Prado, L., and Castilla, J. C. (2012). Territorial user rights for fisheries as ancillary instruments for marine coastal conservation in chile. Conserv. Biol. 26, 1005-1015. doi: 10.1111/j.15231739.2012.01928.x

Gelcich, S., Godoy, N., Prado, L., and Castilla, J. C. (2008). Add-on conservation benefits of marine territorial user rights fishery policies in central chile. Ecol. Appl. 18, 273-281. doi: 10.1890/06-1896.1

Gelcich, S., Martínez-Harms, M. J., Tapia-Lewin, S., Vasquez-Lavin, F., and RuanoChamorro, C. (2019). Comanagement of small-scale fisheries and ecosystem services. Conserv. Lett. 12:e12637. doi: 10.1111/conl.12637

Gelcich, S., Peralta, L., Donlan, C. J., Godoy, N., Ortiz, V., Tapia-Lewin, S., et al. (2015). Alternative strategies for scaling up marine coastal biodiversity conservation in chile. Mar. Stud. 14:5.

Gentry, R. R., Froehlich, H. E., Grimm, D., Kareiva, P., Parke, M., Rust, M., et al. (2017). Mapping the global potential for marine aquaculture. Nat. Ecol. Evol. 1:1317. doi: 10.1038/s41559-017-0257-9

George, T. S. (2002). Minamata: Pollution and the Struggle for Democracy in Postwar Japan. Cambridge, MA: Harvard University Asia Center.

Giakoumi, S., McGowan, J., Mills, M., Beger, M., Bustamante, R., Charles, A., et al. (2018). Revisiting "success" and "failure" of marine protected areas: a conservation scientist perspective. Front. Mar. Sci. 5:223. doi: 10.3389/fmars. 2018.00223

Golden, C. D., Allison, E. H., Cheung, W. W., Dey, M. M., Halpern, B. S., McCauley, D. J., et al. (2016). Nutrition: fall in fish catch threatens human health. Nat. News 534:317. doi: $10.1038 / 534317$ a

Govan, H., and Jupiter, S. (2013). Can the IUCN 2008 protected areas management categories support Pacific island approaches to conservation. Parks 19, 73-80. doi: 10.2305/iucn.ch.2013.parks-19-1.hg.en

Graham, B., Reilly, W. K., Beinecke, F., Boesch, D. F., Garcia, T. D., Murray, C. A., et al. (2011). Deep Water: The Gulf Oil Disaster and the Future of Offshore Drilling. Report to the President. New York, NY: National Commission on the BP Deepwater Horizon Spill and Offshore Drilling (US).

Gregory, R., Failing, L., Harstone, M., Long, G., McDaniels, T., and Ohlson, D. (2012). Structured Decision Making: A Practical Guide To Environmental Management Choices. Hoboken, NJ: John Wiley \& Sons.

Guannel, G., Arkema, K., Ruggiero, P., and Verutes, G. (2016). The power of three: coral reefs, seagrasses and mangroves protect coastal regions and increase their resilience. PLoS One 11:e0158094. doi: 10.1371/journal.pone.0158094

Gurney, G. G., Cinner, J., Ban, N. C., Pressey, R. L., Pollnac, R., Campbell, S. J., et al. (2014). Poverty and protected areas: an evaluation of a marine integrated conservation and development project in indonesia. Glob. Environ. Chang. 26, 98-107. doi: 10.1098/rstb.2014.0277

Hallegatte, S., and Mach, K. J. (2016). Make climate-change assessments more relevant. Nat. News 534:613. doi: 10.1038/534613a

Halpern, B. S. (2003). The impact of marine reserves: do reserves work and does reserve size matter? Ecol. Appl. 13, S117-S137.

Halpern, B. S., Cottrell, R. S., Blanchard, J. L., Bouwman, L., Froehlich, H. E., Gephart, J. A., et al. (2019). Opinion: putting all foods on the same table: achieving sustainable food systems requires full accounting. Proc. Natl. Acad. Sci. U.S.A. 116, 18152-18156. doi: 10.1073/pnas.1913308116

Halpern, B. S., Longo, C., Hardy, D., McLeod, K. L., Samhouri, J. F., Katona, S. K., et al. (2012). An index to assess the health and benefits of the global ocean. Nature 488:615. doi: 10.1038/nature11397

Harada, M. (1995). Minamata disease: methylmercury poisoning in japan caused by environmental pollution. Crit. Rev. Toxicol. 25, 1-24. doi: 10.3109/ 10408449509089885

Hays, G. C., Bailey, H., Bograd, S. J., Bowen, W. D., Campagna, C., Carmichael, R. H., et al. (2019). Translating marine animal tracking data into conservation policy and management. Trends Ecol. Evol. 34, 459-473.

Hazen, E. L., Scales, K. L., Maxwell, S. M., Briscoe, D. K., Welch, H., Bograd, S. J., et al. (2018). A dynamic ocean management tool to reduce bycatch and support sustainable fisheries. Sci. Adv. 4:eaar3001. doi: 10.1126/sciadv. aar3001

Heip, C., Barange, M., Danovaro, R., Gehlen, M., Grehan, A., Meysman, F., et al. (2011). Climate Change and Marine Ecosystem Research: Synthesis of European Research on the Effects of Climate Change on Marine Environments. Ostend: Marine Board.

Hoegh-Guldberg, O., Jacob, D., Taylor, M., Bindi, M., Brown, S., Camilloni, I., et al. (2018). "Impacts of 1.5C global warming on natural and human systems," in Global Warming of 1.5C. An IPCC Special Report on the Impacts of Global Warming of 1.5C Above Pre-Industrial Levels And Related Global Greenhouse Gas Emission Pathways, in the Context Of Strengthening The Global Response to the Threat Of Climate Change, Sustainable Development, And Efforts To Eradicate Poverty, eds V. Masson-Delmotte, P. Zhai, H. O. Pörtner, D. Roberts, J. Skea, P. Shukla, et al. (Geneva: Intergovernmental Panel on Climate Change). Inayatullah, S. (2003). Ageing: alternative futures and policy choices. Foresight 5, 8-17. doi: 10.1108/14636680310698793

International Council for Science [ICSU], (2017). A Guide to SDG Interactions: from Science to Implementation. Paris: International Council for Science.

IPCC, (2019). IPCC Special Report on the Ocean and Cryosphere in a Changing Climate. (Geneva: IPCC).

Jackson, J. B. (2010). The future of the oceans past. Philos. Trans. R. Soc. B Biol. Sci. $365,3765-3778$.

Jackson, J. B., Kirby, M. X., Berger, W. H., Bjorndal, K. A., Botsford, L. W., Bourque, B. J., et al. (2001). Historical overfishing and the recent collapse of coastal ecosystems. Science 293, 629-637. doi: 10.1126/science.1059199

Jahn, T., and Keil, F. (2015). An actor-specific guideline for quality assurance in transdisciplinary research. Futures 65, 195-208. doi: 10.1016/j.futures.2014. 10.015

Jupiter, S. (2017). Culture, kastom and conservation in melanesia: what happens when worldviews collide? Pac. Conserv. Biol. 23, 139-145.

Kantor's Four-Player Model, D. (2012). Reading the Room: Group Dynamics For Coaches And Leaders, Vol. 5. Hoboken, NJ: John Wiley \& Sons.

Kleiber, D., Frangoudes, K., Snyder, H. T., Choudhury, A., Cole, S. M., Soejima, K., et al. (2017). "Promoting gender equity and equal- ity through the small-scale fisheries guidelines: experiences from multiple case studies," in The Small-Scale Fisheries Guidelines, Vol. 14, eds S. Jentoft, R. Chuenpagdee, M. BarragPaladines, and N. Franz, (Amsterdam: Amsterdam University Press), 737-759. doi: 10.1007/978-3-319-55074-9_35

Kleiber, D., Harris, L. M., and Vincent, A. C. (2015). Gender and small-scale fisheries: a case for counting women and beyond. Fish Fish. 16, 547-562. doi: 10.1111/faf.12075

Klein, C., McKinnon, M. C., Wright, B. T., Possingham, H. P., and Halpern, B. S. (2015). Social equity and the probability of success of biodiversity conservation. Glob. Environ. Chang. 35, 299-306. doi: 10.1073/pnas.1217689110

Kollmuss, A., and Agyeman, J. (2002). Mind the gap: why do people act environmentally and what are the barriers to pro-environmental behavior? Environ. Educ. Res. 8, 239-260. doi: 10.1080/13504620220145401

Lang, D. J., Wiek, A., Bergmann, M., Stauffacher, M., Martens, P., Moll, P., et al. (2012). Transdisciplinary research in sustainability science: practice, principles, and challenges. Sustainabil. Sci. 7, 25-43. doi: 10.3390/ijerph120606027

Leisher, C., Temsah, G., Booker, F., Day, M., Samberg, L., Prosnitz, D., et al. (2016). Does the gender composition of forest and fishery management groups affect resource governance and conservation outcomes? A systematic map. Environ. Evid. 5, 1-10.

Lindstrom, E., Gunn, J., Fischer, A., MCCurdy, A., Glover, L. K., Alversen, K., et al. (2012). A Framework for Ocean Observing. Paris: UNESCO.

Lubchenco, J., Cerny-Chipman, E. B., Reimer, J. N., and Levin, S. A. (2016). The right incentives enable ocean sustainability successes and provide hope for the future. Proc. Natl. Acad. Sci. U.S.A. 113, 14507-14514. doi: 10.1073/pnas. 1604982113

Lynch, A. J. J., Thackway, R., Specht, A., Beggs, P. J., Brisbane, S., Burns, E. L., et al. (2015). Transdisciplinary synthesis for ecosystem science, policy and management: the australian experience. Sci. Total Environ. 534, 173-184. doi: 10.1016/j.scitotenv.2015.04.100

Mascia, M. B., Claus, C. A., and Naidoo, R. (2010). Impacts of marine protected areas on fishing communities. Conserv. Biol. 24, 1424-1429. doi: 10.1111/j. 1523-1739.2010.01523.x 
Maxwell, S. M., Hazen, E. L., Lewison, R. L., Dunn, D. C., Bailey, H., Bograd, S. J., et al. (2015). Dynamic ocean management: defining and conceptualizing realtime management of the ocean. Mar. Policy 58, 42-50. doi: 10.1016/j.marpol. 2015.03.014

McCauley, D. J., Woods, P., Sullivan, B., Bergman, B., Jablonicky, C., Roan, A., et al. (2016). Ending hide and seek at sea. Science 351, 1148-1150. doi: 10.1126/ science.aad 5686

McLeod, E., Arora-Jonsson, S., Masuda, Y. J., Bruton-Adams, M., Emaurois, C. O., Gorong, B., et al. (2018). Raising the voices of Pacific Island women to inform climate adaptation policies. Mar. Policy 93, 178-185. doi: 10.1016/j.marpol. 2018.03.011

McLeod, E., Chmura, G. L., Bouillon, S., Salm, R., Björk, M., Duarte, C. M., et al. (2011). A blueprint for blue carbon: toward an improved understanding of the role of vegetated coastal habitats in sequestering CO2. Front. Ecol. Environ. 9, 552-560. doi: 10.1890/110004

McLeod, E., and Palmer, M. (2015). Why conservation needs religion. Coast. Manag. 43, 238-252. doi: 10.1111/cobi.13407

Merrie, A., Keys, P., Metian, M., and Österblom, H. (2018). Radical ocean futuresscenario development using science fiction prototyping. Futures 95, 22-32. doi: 10.1016/j.futures.2017.09.005

Monfort, M. C. (2015). "The role of women in the seafood industry," in GLOBEFISH Research Programme, Vol. 119. Rome: FAO.

Montambault, J. R., Dormer, M., Campbell, J., Rana, N., Gottlieb, S., Legge, J., et al. (2018). Social equity and urban nature conservation. Conserv. Lett. 11:e12423. doi: 10.3390/ijerph16214302

Morioka, K. (2016). Time to Act on Gender, Climate Change and Disaster Risk Reduction. Kabul: UN Women Regional Office for Asia and the Pacific.

Mukherjee, N., Huge, J., Sutherland, W. J., McNeill, J., Van Opstal, M., DahdouhGuebas, F., et al. (2015). The Delphi technique in ecology and biological conservation: applications and guidelines. Methods Ecol. Evol. 6, 1097-1109. doi: 10.1111/2041-210x.12387

Narayan, S., Beck, M. W., Wilson, P., Thomas, C. J., Guerrero, A., Shepard, C. C., et al. (2017). The value of coastal wetlands for flood damage reduction in the Northeastern USA. Sci. Rep. 7:9463. doi: 10.1038/s41598-017-09269-z

National Oceanic and Atmospheric Administration and National Marine Fisheries Service [NOAA-NMFS], (2017). Fisheries Economics of the United States 2015. Silver Spring, MD: NOAA.

O’Neill, B. C., Kriegler, E., Ebi, K. L., Kemp-Benedict, E., Riahi, K., Rothman, D. S., et al. (2017). The roads ahead: narratives for shared socioeconomic pathways describing world futures in the 21st century. Glob. Environ. Chang. 42, 169-180. doi: 10.1016/j.gloenvcha.2015.01.004

Parsons, E. C., Favaro, B., Aguirre, A. A., Bauer, A. L., Blight, L. K., Cigliano, J. A., et al. (2014). Seventy-one important questions for the conservation of marine biodiversity. Conserv. Biol. 28, 1206-1214. doi: 10.1111/cobi.12303

Pendleton, L., Comte, A., Langdon, C., Ekstrom, J. A., Cooley, S. R., Suatoni, L., et al. (2016). Coral reefs and people in a high-CO2 world: where can science make a difference to people? PLoS One 11:e0164699. doi: 10.1371/journal.pone. 0164699

Pendleton, L., Donato, D. C., Murray, B. C., Crooks, S., Jenkins, W. A., Sifleet, S., et al. (2012). Estimating global "blue carbon" emissions from conversion and degradation of vegetated coastal ecosystems. PLoS One 7:e43542. doi: 10.1371/journal.pone.0043542

Puma, M. J., Bose, S., Chon, S. Y., and Cook, B. I. (2015). Assessing the evolving fragility of the global food system. Environ. Res. Lett. 10:024007. doi: 10.1088/ 1748-9326/10/2/024007

Quimby, B., and Levine, A. (2018). Participation, power, and equity: examining three key social dimensions of fisheries comanagement. Sustainability 10:3324. doi: $10.3390 /$ su10093324

Reed, M. S. (2008). Stakeholder participation for environmental management: a literature review. Biol. Conserv. 141, 2417-2431. doi: 10.1016/j.biocon.2008. 07.014

Reguero, B. G., Beck, M. W., Bresch, D. N., Calil, J., and Meliane, I. (2018). Comparing the cost effectiveness of nature-based and coastal adaptation: a case study from the Gulf Coast of the United States. PLoS One 13:e0192132. doi: 10.1371/journal.pone.0192132

Reich, S. M., and Reich, J. A. (2006). Cultural competence in interdisciplinary collaborations: a method for respecting diversity in research partnerships. Am. J. Commun. Psychol. 38, 1-7. doi: 10.1007/s10464-006-9064-1
Rilov, G., Mazaris, A. D., Stelzenmuller, V., Helmuth, B., Wahl, M., Guy-Haim, T., et al. (2019). Adaptive marine conservation planning in the face of climate change: what can we learn from physiological, genetic and ecological studies? Glob. Ecol. Conserv. 17:e00566. doi: 10.1016/j.gecco.2019.e00566

Rogelj, J., Shindell, D., Jiang, K., Fifita, S., Forster, P., Ginzburg, V., et al. (2018). "Mitigation pathways compatible with $1.5 \mathrm{C}$ in the context of sustainable development," in Global Warming of 1.5C. An IPCC Special Report on the Impacts Of Global Warming of 1.5C Above Pre-Industrial Levels And Related Global Greenhouse Gas Emission Pathways, in the Context Of Strengthening the Global Response to the Threat Of Climate Change, Sustainable Development, And Efforts To Eradicate Poverty, eds V. Masson-Delmotte, P. Zhai, H. O. Pörtner, D. Roberts, J. Skea, P. R. Shukla, et al. (Geneva: Intergovernmental Panel on Climate Change).

Rollier, B., and Turner, J. A. (1994). Planning forward by looking backward: retrospective thinking in strategic decision making. Decision Sci. 25, 169-188. doi: 10.1111/j.1540-5915.1994.tb01838.x

Roskos-Ewoldsen, D. R., Roskos-Ewoldsen, B., and Carpentier, F. R. D. (2009). "Media priming: an updated synthesis," in Media Effects: Advances in Theory and Research, eds J. Bryant, and M. B. Oliver, (Abingdon: Routledge), 74-93.

Rudd, M. A. (2014). Scientists perspectives on global ocean research priorities. Front. Mar. Sci. 1:36. doi: 10.3389/fmars.2014.00036

Sabine, C. L., Feely, R. A., Gruber, N., Key, R. M., Lee, K., Bullister, J. L., et al. (2004). The oceanic sink for anthropogenic CO2. Science 305, 367-371. doi: $10.1126 /$ science. 1097403

Saffo, P. (2007). Six rules for effective forecasting. Harv. Bus. Rev. 85:122.

Schultz, P. W., Nolan, J. M., Cialdini, R. B., Goldstein, N. J., and Griskevicius, V. (2007). The constructive, destructive, and reconstructive power of social norms. Psychol. Sci. 18, 429-434. doi: 10.1111/j.1467-9280.2007.01917.x

Selin, N. E., and Selin, H. (2006). Global politics of mercury pollution: the need for multi-scale governance. Rev. Eur. Commun. Int. Environ. Law 15, 258-269. doi: 10.1111/j.1467-9388.2006.00529.x

Sorensen, C., Murray, V., Lemery, J., and Balbus, J. (2018). Climate change and women's health: impacts and policy directions. PLoS Med. 15:e1002603. doi: 10.1371/journal.pmed.1002603

Spalding, M., Burke, L., Wood, S. A., Ashpole, J., Hutchison, J., and Zu Ermgassen, P. (2017). Mapping the global value and distribution of coral reef tourism. Mar. Policy 82, 104-113. doi: 10.1016/j.marpol.2017.05.014

Spalding, M. D., Mcivor, A. L., Beck, M. W., Koch, E. W., Möller, I., Reed, D. J., et al. (2014). Coastal ecosystems: a critical element of risk reduction. Conserv. Lett. 7, 293-301. doi: 10.1016/j.jenvman.2016.05.032

Stephens, N., Dunsford, I., Di Silvio, L., Ellis, M., Glencross, A., and Sexton, A. (2018). Bringing cultured meat to market: technical, socio-political, and regulatory challenges in cellular agriculture. Trends Food Sci. Technol. 78, 155-166. doi: 10.1016/j.tifs.2018.04.010

Sterling, E. J., Betley, E., Sigouin, A., Gomez, A., Toomey, A., Cullman, G., et al. (2017). Assessing the evidence for stakeholder engagement in biodiversity conservation. Biol. Conserv. 209, 159-171. doi: 10.1016/j.biocon.2017.02.008

Stewart, D. W., Pavlou, P., and Ward, S. (2002). "Media influences on marketing communications," in Media Effects: Advances in Theory and Research, eds J. Bryant, and D. Zillman, (Mahwah, NJ: Erlbaum Associates), 353-396.

Sutherland, W. J., Butchart, S. H., Connor, B., Culshaw, C., Dicks, L. V., Dinsdale, J., et al. (2018). A 2018 horizon scan of emerging issues for global conservation and biological diversity. Trends Ecol. Evol. 33, 47-58. doi: 10.1016/j.tree.2017. 11.006

Sydeman, W. J., Santora, J. A., Thompson, S. A., Marinovic, B., and Lorenzo, E. D. (2013). Increasing variance in North Pacific climate relates to unprecedented ecosystem variability off California. Glob. Chang. Biol. 19, 1662-1675. doi: 10.1111/gcb.12165

Teh, L. C., and Sumaila, U. R. (2013). Contribution of marine fisheries to worldwide employment. Fish Fish. 14, 77-88. doi: 10.1111/j.1467-2979.2011. 00450.x

Thrush, S., Hewitt, J., Cummings, V., Ellis, J., Hatton, C., Lohrer, A., et al. (2004). Muddy waters: elevating sediment input to coastal and estuarine habitats. Front. Ecol. Environ. 2, 299-306. doi: 10.2307/3868405

Tilman, D., and Clark, M. (2014). Global diets link environmental sustainability and human health. Nature 515:518. doi: 10.1038/nature13959 
Tommasi, D., Stock, C. A., Hobday, A. J., Methot, R., Kaplan, I. C., Eveson, J. P., et al. (2017). Managing living marine resources in a dynamic environment: the role of seasonal to decadal climate forecasts. Prog. Oceanogr. 152, 15-49.

United Nations, (2015). Geneneral Assembly Resolution 70/1. Transforming Our World: The 2030 Agenda for Sustainable Development. New York, NY: United Nations.

United Nations Department of Economic and Social Affairs Population Division, (2017). World Population Prospects: The 2017 Revision, Key Findings and Advance Tables. New York, NY: United Nations.

United Nations Framework Convention on Climate Change [UNFCCC], (2015). "Paris Agreement," in Proceedings of the 21st Conference of the Parties of the UNFCCC, New York, NY.

Visbeck, M. (2018). Ocean science research is key for a sustainable future. Nat. Commun. 9, 1-4.

Whitmee, S., Haines, A., Beyrer, C., Boltz, F., Capon, A. G., De Souza Dias, B. F., et al. (2015). Safeguarding human health in the anthropocene epoch: report of the rockefeller foundation-lancet commission on planetary health. Lancet 386, 1973-2028. doi: 10.1016/s0140-6736(15)60901-1

World Bank, (2012). Hidden Harvest: The Global Contribution OfCapture Fisheries. Washington, DC: The World Bank.
World Bank, and United Nations Department of Economic and Social Affairs, (2017). The Potential of the Blue Economy: Increasing Long-term Benefits of the Sustainable Use of Marine Resources for Small Island Developing States and Coastal Least Developed Countries. Washington D.C: World Bank.

Wyborn, C., van Kerkhoff, L., Dunlop, M., Dudley, N., and Guevara, O. (2016). Future oriented conservation: knowledge governance, uncertainty and learning. Biodivers. Conserv 25, 1401-1408. doi: 10.1007/s10531-016-1130-x

Conflict of Interest: The authors declare that the research was conducted in the absence of any commercial or financial relationships that could be construed as a potential conflict of interest.

Copyright (@) 2020 Friedman, Halpern, McLeod, Beck, Duarte, Kappel, Levine, Sluka, Adler, O'Hara, Sterling, Tapia-Lewin, Losada, McClanahan, Pendleton, Spring, Toomey, Weiss, Possingham and Montambault. This is an open-access article distributed under the terms of the Creative Commons Attribution License (CC BY). The use, distribution or reproduction in other forums is permitted, provided the original author(s) and the copyright owner(s) are credited and that the original publication in this journal is cited, in accordance with accepted academic practice. No use, distribution or reproduction is permitted which does not comply with these terms. 